\title{
A TRADUÇÃO EM TEMPOS SOMBRIOS
}

\author{
Davi Andrade Pimentel ${ }^{1}$ \\ 1.Universidade Federal Fluminense, Rio de Janeiro, Rio de Janeiro, Brasil
}

\begin{abstract}
Resumo: A partir do livro As últimas testemunhas, de Svetlana Aleksiévitch, este artigo analisa a tensão entre o traduzível e o intraduzível dos testemunhos dos sobreviventes do Leste Europeu da Segunda Guerra Mundial, partindo de três movimentos de intraduzibilidade: o excesso do real, a falta da palavra e as pseudotestemunhas.

Palavras-chave: Testemunho; Tradução; Segunda Guerra Mundial; Leste Europeu; Svetlana Aleksiévitch
\end{abstract}

\section{THE TRANSLATION IN DARK TIMES}

\begin{abstract}
From Svetlana Aleksiévitch's work, Last witnesses, this paper analyzes the tension between the translatable and the untranslatable testimonies of European East's Second World War's survivors, considering three elements of untranslatability: the excess of the real, the lack of the word and the pseudo-witnesses.
\end{abstract}

Keywords: Testimony; Translation; Second World War; European East; Svetlana Aleksiévitch

Os sentimentos vastos não têm nome. Perdas, deslumbramentos, catástrofes do espírito, pesadelos da carne, os sentimentos vastos não têm boca, fundo de soturnez, mudo desvario, escuros enigmas habitados de vida mas sem sons, assim eu neste instante diante do teu corpo morto. Inventar palavras, quebrá-las, recompô-las, ajustar-me digno diante de tanta ferida...

Hilda Hilst. Rútilo Nada 


\section{Traduzir}

Não tem como contar. Não tem como contar, querida. Não! E não!

(Zina Gúrskaia, sete anos. Hoje: polidora) ${ }^{1}$

Walter Benjamin, em seu texto "Sobre a linguagem em geral e sobre a linguagem do homem", presente no livro Escritos sobre mito e linguagem, nos diz que o homem, a partir do que é comunicável em cada manifestação da vida espiritual humana, ou seja, a partir da essência linguística presente na essência espiritual de cada coisa ou ser, adquire o conhecimento de si mesmo, das coisas e do próprio mundo no ato de nomeação: "Toda natureza, desde que se comunica, se comunica na língua, portanto, em última instância, no homem. Por isso, ele é o senhor da natureza e pode nomear as coisas. É somente através da essência linguística das coisas que ele, a partir de si mesmo, alcança o conhecimento delas - no nome" (Benjamin 56). Conhecimento e comunicação, em Benjamin, têm como base a linguagem, que, por sua vez, assume um papel criador, o de dar uma segunda camada de vida à vida dos seres que já se encontram vivos, uma vez que todos já possuem uma essência espiritual inalienável antes de qualquer nome humano. O mundo já está. Ele é. Deus o criou, deu-lhe um nome puro, não arbitrário, legítimo: "Que a língua do paraíso tenha sido a língua do conhecimento perfeito é algo que nem mesmo a existência da árvore do conhecimento pode dissimular" (Benjamin 66). No entanto, o homem, ao cair na tentação da serpente pela busca do conhecimento, desejoso por saber "o que é bom e o que é mau", não sabendo ele que esse conhecimento é nulo, esvaziado de nome, é expulso do Paraíso e, consequentemente, perde o poder imanente da linguagem pura provinda de Deus, linguagem divina:

\footnotetext{
${ }^{1}$ As citações que abrem cada seção deste artigo pertencem aos testemunhos de adultos da extinta União Soviética - que na Segunda Grande Guerra eram crianças - recolhidos por Svetlana Aleksiévitch em seu livro As últimas testemunhas: crianças na Segunda Guerra Mundial. Esta citação encontra-se na pág.: 89.
} 
O saber sobre o que é bom e o que é mau não tem a ver com o nome, é um conhecimento exterior, a imitação não criativa da palavra criadora. Nesse conhecimento, o nome sai de si mesmo: o pecado original é a hora de nascimento da palavra humana, aquela em que o nome não vivia mais intacto, aquela palavra que abandonou a língua que nomeia, a língua que conhece, pode-se dizer: abandonou a sua própria magia imanente para reivindicar expressamente seu caráter mágico, de certo modo, a partir do exterior. A palavra deve comunicar alguma coisa (afora si mesma). Esse é realmente o pecado original do espírito linguístico. (Benjamin 67, grifo do autor)

A palavra divina por si só se basta, nela compreendido todo e qualquer conhecimento ou ato de conhecimento. O conhecimento, nela, está imanente. Deus condensa o saber absoluto. Mas o homem, ao querer saber o que ultrapassa o divino, ao desejar saber "o que é bom e o que é mau", palavras cujo nome/significado são de irrelevância no Paraíso, uma vez que o possível bom e mau está em Deus, cai em tentação. E nessa tentação, não é preciso lembrar, há um desejo latente da criatura de se equiparar, em conhecimento, ao Criador: “A árvore do conhecimento não estava no jardim de Deus pelas informações que eventualmente pudesse fornecer sobre o bem e o mal, mas sim como insígnia do julgamento sobre aquele que pergunta" (Benjamin 69). No Paraíso, perguntar é pôr em causa Deus, o seu saber absoluto. Deus é, e nada mais - um movimento autoritário e vaidoso não pode ser, aqui, descartado. Como castigo, o homem é atirado à Terra, e com ele a sua linguagem. Em sua desobediência, em outras palavras, em sua busca por conhecimento, o homem é marcado por Deus com uma falta, sobretudo, no que diz respeito à linguagem. No momento da queda, Deus reivindica a sua linguagem pura e imanente e deixa ao homem uma linguagem plural, babélica, desconcertante e arbitrária: "Depois da queda, que, ao tornar a língua mediada, lançou a base para sua pluralidade, não era preci- 
so mais que um passo para se chegar à confusão entre as línguas" (Benjamin 69).

Tendo tudo já sido criado por Deus, tendo cada coisa ou ser a sua palavra divina, tendo o homem perdido a possibilidade da fala pura, resta-lhe sobrenomear as coisas ou, como afirmara antes, resta-lhe dar uma segunda camada de vida (o nome humano) à vida dos seres já existentes (nomeados por Deus): “As coisas não têm nome próprio a não ser em Deus. Pois, certamente, na palavra criadora, Deus as chamou por seu nome próprio. Em contrapartida, na linguagem dos homens, elas estão sobrenomeadas" (Benjamin 71). $\mathrm{E}$, na sobrenomeação das coisas, a falta presente na linguagem - a marca divina imposta ao homem - se revela integralmente, não por menos, cada homem, em cada lugar, sobrenomeia as coisas de modo particular, diferenciado, linguisticamente arbitrário. E por serem arbitrárias, as línguas exigem, ao simples contato com as coisas, tradução - é preciso tornar conhecido o desconhecido: "Traduzir a linguagem das coisas para a linguagem do homem não consiste apenas em traduzir o que é mudo para o que é sonoro, mas em traduzir aquilo que não tem nome em nome. Trata-se, portanto, da tradução de uma língua imperfeita para uma língua mais perfeita, e ela não pode deixar de acrescentar algo, o conhecimento" (Benjamin 64-5). Na leitura do texto benjaminiano, a tradução entre a língua das coisas e a língua dos homens ocorre na língua do próprio homem, ou seja, essa tradução do tornar conhecido as coisas a partir do nome dado a elas ocorre a todo instante na língua portuguesa, francesa, alemã, dentre outras. É uma tradução característica da língua e de todo ato de linguagem e de comunicação entre homens, sejam eles de uma mesma nacionalidade ou não, de um mesmo dialeto ou não, de uma mesma ideia de mundo ou não, pois compreender é traduzir, adquirir conhecimento é traduzir.

A tradução, para além da tradução entre as línguas, se dá na própria língua, uma vez que a falta está na base da linguagem humana, é a marca do pecado original, como nos lembra Benjamin. Antes, a "vida do homem no puro espírito da linguagem era bem -aventurada" (Benjamin 69), estando com Deus, em Sua absoluta 
imanência, o homem não precisava traduzir as coisas, ou melhor, conhecê-las, compreendê-las, pois elas já eram conhecidas, não havendo a possibilidade do desconhecido macular a supremacia divina: Deus era o conhecimento onipresente no Paraíso. Agora, caído em desgraça, em meio a tantas línguas, o homem precisa da tradução para conhecer, compreender e comunicar. A tradução surge, de fato, como compreensão:

O modelo 'emissor para receptor' que representa qualquer processo semiótico e semântico é equivalente ontologicamente ao modelo 'língua de partida para língua de chegada' usado na teoria da tradução. Em ambos os esquemas, há 'no meio' uma operação de decifração interpretativa, uma função codificadora-decodificadora, uma sinapse. [...] Em suma: entre línguas ou no interior de uma língua, a comunicação humana é igual à tradução. Um estudo da tradução é um estudo da linguagem. (Steiner 72, grifo do autor)

Ou seja, no exercício de conhecimento do mundo, como sugere George Steiner, em "A compreensão como tradução", no livro Depois de Babel, o homem exerce o seu papel de tradutor, principalmente, no ato de comunicação, que o leva ao ato de nomeação ou, lembrando Benjamin, ao ato de sobrenomeação. Nomear na língua aquilo que antes não conhecíamos ou compreendíamos está intimamente relacionado à tradução do desconhecido em conhecido. O conceito de tradução, neste artigo, está amplamente associado à ideia de tradução enquanto compreensão apresentada por Steiner e à falta da linguagem decorrente do pecado original sugerida por Benjamin. Exatamente por ser faltosa e arbitrária, a linguagem, para ser comunicada, precisa ser traduzida na própria língua, sendo o ato de linguagem um ato de tradução constante: "Qualquer modelo da comunicação é simultaneamente um modelo da tradução, de uma transferência horizontal ou vertical de significação" (Steiner 70). Contudo, o que ocorre quando nos deparamos com o testemunho desta cena?: 
As mulheres e as crianças corriam atrás deles [prisioneiros russos ou partisans]. Os alemães os faziam andar rápido. Ficamos para trás. Quando alcançamos correndo o último galpão, ouviram-se tiros. As pessoas começaram a cair; ora caíam, ora se levantavam. Terminaram de atirar neles rapidamente e estavam se preparando para ir embora. Um alemão de moto virou e contornou aquelas pessoas mortas. Ele tinha algo pesado na mão... Um porrete ou a manivela da moto... Não lembro... Sem descer da moto, ele foi andando lentamente e quebrando todas as cabeças... Outro alemão queria terminar de matar as pessoas com a pistola, aquele fez um sinal com as mãos como quem diz "não precisa". Todos saíram, mas ele não foi embora até quebrar todas as cabeças. Antes disso, eu nunca havia escutado ossos humanos estalando... Me ficou na memória que eles estalavam como abóboras maduras quando meu pai as cortava com um machado, e eu recolhia as sementes. (Aleksiévitch (b) 214-5)

Esse testemunho pertence a Iákov Kolodínsk, que, na época da Segunda Grande Guerra, na Bielorrússia, tinha sete anos. Atualmente, quando do registro de seu testemunho efetuado pela jornalista e escritora Svetlana Aleksiévitch, em seu livro As últimas testemunhas: crianças na Segunda Guerra Mundial, exerce a profissão de professor escolar. Em seu testemunho, é perceptível uma certa falta em sua fala, algo soçobra no que diz, algo resta intraduzível da cena que presenciou quando criança. Como traduzir essa imagem? Como tornar a imagem do massacre em massa em algo comunicável, traduzível? A associação do som das cabeças sendo quebradas ao som/imagem das abóboras sendo cortadas por seu pai, além de ser inteiramente infantil, infantil enquanto marca da logística do pensamento pueril, resgata uma característica inata da criança: a falta de um julgamento pré-formado do que seria bom ou mau. Em seu testemunho, Iákov não imprime um julgamento à ação do nazista, ele apenas a relata e a associa, infantilmente, a uma cena cotidiana sua com o seu pai. O discernimento do bem e do mal não nasce com a criança, ele é construído, como sabemos através 
da psicanálise, sobretudo, com Freud. E esse discernimento podemos analisá-lo segundo o texto de Benjamin. É provável que Deus, ao barrar o homem, tornando-lhe nula a ideia do que seria bom e mau, estivesse, na verdade, protegendo a sua criatura. Sendo Deus a onipotência e o Bem em sua extensão mais pulsante, não haveria necessidade da compreensão, por parte do homem, do Mal. Seria como se Deus protelasse ou encobrisse a predisposição do homem à sua destruição, pois, uma vez tendo compreendido a diferença entre o bem e o mal, o homem tendesse instintivamente ao mal, ao desejo irrefreável de suplantar o próximo: "Por acaso há algo mais pavoroso que o homem? (Novamente se cala)" (Aleksiévitch (a) 93).

Então, o que falta? O que não se traduz? Quando nos deparamos com acontecimentos que excedem o vivível, o dizível e o conhecível, a tradução se apresenta falha, uma vez que a linguagem, necessária à tradução, não suporta a contingência dos fatos que colocam em causa a própria palavra. Nesses momentos de grandes massacres, das pequenas e das grandes guerras, para que serve a palavra? Para que traduzir, reviver, o acontecido? Para lembrar ao sobrevivente que ele sobreviveu? Para lembrar ao futuro o que não pode nunca mais ocorrer? Infelizmente, como nos diz Hannah Arendt, em Eichmann em Jerusalém: um relato sobre a banalidade do mal:

Faz parte da própria natureza das coisas humanas que cada ato cometido e registrado pela história da humanidade fique com a humanidade como uma potencialidade, muito depois da sua efetividade ter se tornado coisa do passado. Nenhum castigo jamais possuiu poder suficiente para impedir a perpetração de crimes. Ao contrário, a despeito do castigo, uma vez que um crime específico apareceu pela primeira vez, sua reaparição é mais provável do que poderia ter sido a sua emergência inicial. (Arendt 295-6)

A literatura de testemunho seria uma experiência na qual se demonstraria a possibilidade do intraduzível? Possivelmente. Quando o homem passa por uma experiência tão traumática, como a ocorrida 
com Iákov, a falta presente na linguagem se alastra de modo irreversível. A língua cede ao trauma, impossibilita a fala, a palavra se torna vã e o testemunho torna-se algo impraticável, mesmo quando testemunhado: "Um evento como o trauma externo vai gerar uma enorme perturbação no gerenciamento de energia do organismo e pôr em movimento todos os meios de defesa" (Freud 192). Um dos meios de defesa comumente compartilhado por sobreviventes é a mudez, em dois aspectos: a mudez que precede à fala, ou seja, não há a possibilidade da testemunha comunicar/traduzir/compreender o ocorrido e a mudez/falta que percorre todo e qualquer testemunho registrado. A falta - que está na linguagem e que é consolidada pelo trauma:

a história do trauma é a história de um choque violento, mas também de um desencontro com o real (em grego, vale lembrar, 'trauma' significa ferida). A incapacidade de simbolizar o choque - o acaso que surge com a face da morte e do inimaginável" (Seligmann-Silva 49).

A intraduzibilidade, a mudez falada, percorre todos os testemunhos registrados por Svetlana Aleksiévitch, em As últimas testemunhas, eis alguns fragmentos: "Passei muito tempo sem falar. Só olhava" (09), "Minha avó passou muito tempo calada, calada, mas à noite começou a chorar" (29), "As pessoas ficaram mudas e surdas" (30), "Nos apertávamos mais uns contra os outros, um dizia algo para o outro, mas não com palavras, e sim com movimentos da mão, com os olhos" (129), "Ao ouvir o sino que havia tempos estava morto, a aldeia ficou muda" (160).

\section{Intraduzível}

Quando eu entendi que era um pedaço de uma pessoa que estava pendurado na árvore, fiquei pasma. Fechei os olhos...

(Inna Levkiévitch, dez anos. Hoje: engenheira civil) 
Na leitura dos testemunhos registrados no livro de Aleksiévitch, As últimas testemunhas, destacam-se três movimentos tensionados entre o traduzível e o intraduzível, entre a compreensão e a incompreensão das cenas vivenciadas pelas testemunhas da Segunda Grande Guerra. Neste artigo, essa tensão está inscrita na palavra "intraduzível”, na qual o prefixo in- está em itálico para assinalar esse campo de forças presente na fala (muda) das testemunhas, essa tensão em que o possível de uma tradução tem como contrapartida a sua intraduzibilidade:

de um lado, a necessidade premente de narrar a experiência vivida; do outro, a percepção tanto da insuficiência da linguagem diante de fatos (inenarráveis) como também - e com um sentido muito mais trágico - a percepção do caráter inimaginável dos mesmos e da sua consequente inverossimilhança (Seligmann-Silva 46).

Os três movimentos de intraduzibilidade são: o excesso do real, a falta da palavra e as pseudotestemunhas.

\section{1. o excesso do real}

Não quero lembrar... Não quero lembrar, nunca quero... (Vália Emitróvitch, onze anos. Hoje: operária)

Os sobreviventes das grandes guerras têm, logo de imediato, uma dificuldade de compreensão do real vivido, uma dificuldade em traduzir na língua os momentos traumáticos pelos quais passaram, quando foram expostos à fome, ao massacre de familiares, de conhecidos e de desconhecidos e à suspensão absoluta de seus direitos civis e políticos como ser humano. Em As últimas testemunhas, Zoia Majárova testemunha: 
Sede... A sede nos torturava a todos, estávamos o tempo inteiro com vontade de beber algo. [...] No canto ficavam uns baldes, que usávamos para fazer as necessidades enquanto viajávamos. E uma menina... Ela rastejou até esses baldes, pegou um com as mãos, se aferrou nele e começou a beber. Bebia com grandes goles... Depois começou a se retorcer... Ela vomitou e rastejou até o balde de novo... Se retorceu de novo... (Aleksiévitch (b)121)

A viagem era para um campo de concentração em Magdeburg, na Alemanha nazista. Em um vagão lotado de crianças raptadas no Domingo de Ramos, impedidas de se acomodarem porque eram tantas que a única possibilidade de fazerem a viagem era de pé, umas coladas às outras, Zoia, então com doze anos, presencia essa cena, cuja tradução completa é impossível. A lacuna em seu testemunho é sentida no silêncio recorrente representado pelas reticências em sua fala, como se algo ainda não se adequasse à realidade, como se o evento vivenciado, por ser tão absurdo e fora do concebível, excedesse a realidade, passasse a ser uma imaginação de criança, uma imaginação perversa, diga-se de passagem: "Trata-se de fatos tão reais que, comparativamente, nada é mais verdadeiro; uma realidade que excede necessariamente os seus elementos factuais: é esta a aporia de Auschwitz" (Agamben 20). A aporia de Auschwitz, analisada por Giorgio Agamben, em seu livro $O$ que resta de Auschwitz, é a aporia de todos os sobreviventes da Alemanha nazista, sobretudo, os sobreviventes do Leste Europeu, de onde vem os testemunhos recolhidos por Svetlana Aleksiévitch. Atualmente, sabemos dos massacres ocorridos nas aldeias e nas cidades da Rússia, da Bielorrússia e da Polônia, por exemplo, nas quais a ação dos Einsatzgruppen (unidade móvel de assassinato no Leste) era de extremo genocídio: “As 'diferentes unidades' foram selecionadas entre grupos de matadores que operavam na retaguarda do Exército no Leste, e cujo dever especial consistia em massacrar a população civil nativa, e, especialmente, os judeus" (Arendt 93). 
O "alemão de moto", no testemunho de Iákov, era membro de uma das unidades dos Einsatzgruppen. No Leste Europeu, a realidade excedia não apenas para os judeus, como fica claro no registro de Hannah Arendt, mas também para a população nativa das localidades invadidas pelos nazistas. Esse massacre em massa tinha um objetivo: Hitler declarava precisar de um espaço judenrein (livre de judeus) e, principalmente, volkloser Raum (espaço vazio) na Europa centro-oriental para o estabelecimento de alemães, o que, nas entrelinhas, estava subtendido o genocídio em massa da população nativa, por isso a reiterada violência intraduzível dos alemães nos testemunhos dos sobreviventes: "Vimos uma família subir no barco: marido, esposa e dois filhos; quando [os nazistas] viraram o barco, os adultos foram imediatamente para o fundo, e as crianças boiavam. Os fascistas, rindo, batiam nelas com os remos" (Aleksiévitch (b) 208). Junto com a violência nazista, temos duas consequências drásticas: o colapso moral e a banalidade do mal - duas consequências que, como veremos, problematizam a tradução do real. Na tentativa de salvar a própria pele, alguns nativos se dispunham a colaborar com o Exército alemão na denúncia de famílias judias, de funcionários comunistas e de membros da resistência (partisans), recebendo a alcunha de politsai: "Os politsai diziam: 'É um luxo deixar uns bandidos partisans como vocês num lugar tão bonito. Vamos deixar vocês na sujeira"” (Aleksiévitch (b) 219). Interessa lembrar que aquele que chama o outro de bandido era o seu vizinho antes da guerra, era aquele com quem se mantinha uma relação de (suposta) amizade, de cordialidade e de respeito.

A mudez da testemunha, que invariavelmente está testemunhando, consiste em não compreender a realidade que se apresenta aos seus olhos em um momento tão crítico quanto o massacre de inocentes, orquestrado, por sua vez, por vizinhos, conhecidos, pessoas com quem se mantinha um laço de afeto - esse é o verdadeiro colapso moral que acompanhou o genocídio nazista: o "colapso moral que os nazistas provocaram na respeitável sociedade europeia - não apenas na Alemanha, mas em quase todos os países, não só entre os perseguidores, mas também entre as vítimas" (Arendt 
142). A aceitação por parte da população alemã dos crimes nazistas e a cooperação das vítimas do Leste que denunciavam as vítimas "principais" fazem com que passemos a considerar a inversão dos conceitos básicos de certo e de errado que se realizou no período do sucesso da política hitleriana:

E assim como a lei de países civilizados pressupõe que a
voz da consciência de todo mundo dita 'Não matarás', mes-
mo que o desejo e os pendores do homem natural sejam
às vezes assassinos, assim a lei da terra de Hitler ditava à
consciência de todos: 'Matarás', embora os organizadores
dos massacres soubessem muito bem que o assassinato era
contra os desejos e os pendores normais da maioria das
pessoas (Arendt 167)

Mais uma vez nos perguntamos: será essa a razão de Deus ter proibido ao homem o fruto do conhecimento? Ele já sabia que o conhecimento do "que é bom e o que é mau" pelo homem desencadearia em consequências inimagináveis, como o genocídio em massa? Pois Hitler julgava estar correto e os judeus errados: "Realmente, para a palavra que julga, o conhecimento do bem e do mal é imediato" (Benjamin 67). E a intraduzibilidade, por parte da testemunha, está correlacionada a essa inversão do que seria o certo e o errado por parte daqueles que perpetravam os crimes. Como traduzir a corrupção de um conceito há tempos estabelecido pelo próprio homem? Para alguns, a possibilidade de salvação estava na delação e na morte dos demais; todavia, para a maioria dos que sobreviveram, a salvação estava na garantia da vida dos inocentes, como postulava a resistência do Leste Europeu. Com o fim da guerra, os nazistas, em sua defesa, diziam que estavam apenas cumprindo ordens, que, na realidade, a culpa toda seria do Führer, uma vez que, como soldados, eles lhe deviam obediência. Contudo, sabemos, pela extensa literatura sobre fatos de guerra, que uma ordem superior pode ser desacatada se for comprovada 
a sua ilegalidade, como, por exemplo, o assassinato específico de judeus ou o assassinato de uma população nativa:

Em termos práticos, porém, para serem desobedecidas, as ordens têm de ser 'manifestamente ilegais', e a ilegalidade tem de "parar como uma bandeira negra acima [delas] como um aviso de "Proibido" - conforme o tribunal indicou" (Arendt 165-6).

Matar um inocente não pode ser compreendido como uma ordem legal e aquele que "acredita" na normalidade da morte de um inocente está se autoenganando e se autocorrompendo: "Se isso significava nada mais que prestar obediência cega às ordens do Führer, todos eles haviam sido pequenos dentes da engrenagem" (Arendt 70).

$\mathrm{E}$, aqui, nos deparamos com a banalidade do mal: o massacre de milhões de inocentes por motivos puramente ideológicos, pífios, sem nenhuma razão ou direito de ser praticado. "Evacuar e deportar judeus era coisa de rotina; o que ficou em sua cabeça [na de Eichmann] foi o boliche, foi ser hóspede de um ministro, foi ficar sabendo do ataque contra Heydrich" (Arendt 96). Quando o assassínio de judeus passa a se tornar rotina, há nessa banalidade cotidiana uma responsabilidade que excede o campo nazista, recaindo na responsabilidade de toda uma estrutura mundial que, menos ou mais, compactuava, consciente ou não, com esse massacre: "era de grande interesse político saber quanto tempo leva uma pessoa mediana para superar sua repugnância inata pelo crime, e o que exatamente acontece com essa pessoa quando chega a esse ponto" (Arendt 109). Acreditar na superioridade de uma raça, acreditar que o outro passa a ser inferior por não compartilhar de uma mesma cultura, e por isso se torna passível de exterminação, é de uma banalidade que, como veremos, mata, cega, vilipendia, corrompe, denigre, esmaga e dá prazer: 
'Sem dúvida sou duro e estou pronto a ajudar na solução [extermínio] da questão judaica', Kube [administrador civil alemão da região da Bielorrússia] escreveu a seu superior em dezembro de 1941, 'mas pessoas que vêm do mesmo meio cultural que o nosso sem dúvida são diferentes das hordas nativas animalizadas' (Arendt 112)

Em As últimas testemunhas, de todas as banalidades do mal que encontramos nos relatos dos sobreviventes, dois testemunhos são bastante reveladores - o primeiro é de Sacha Kávrus e o segundo é de Liuba Aleksandróvitch:

Na minha lembrança ficou uma cena de uns alemães perseguindo galinhas. Pegavam, erguiam e torciam até que a cabeça ficasse nas mãos. Gargalhavam. Me parecia que nossas galinhas gritavam... Feito gente... Com voz de gente... Os gatos e os cachorros também, quando eram abatidos a tiros... (Aleksiévitch (b) 79)

Os alemães iam pelas khatas. Juntaram os que tinham filhos entre os partisans... E cortavam a cabeça deles com um machado no meio da aldeia... Ordenavam: olhe. Numa khata não encontraram ninguém, capturaram e enforcaram o gato. Ele ficou pendurado na cordinha, feito uma criança... (Aleksiévitch (b) 85)

A racionalidade, a cultura diferenciada e a ideia de superioridade tão presentes na distinção feita pelos nazistas em relação às "hordas nativas animalizadas" caem por terra quando lemos esses dois testemunhos, em que as figuras centrais são os animais. A bestialidade alemã se torna tão visceral, em contraposição ao animal, à morte banalíssima de um animal por simples prazer - chega a ser aterrador o riso e a gargalhada dos alemães no cumprimento de seus crimes -, que eles, os alemães, perdem toda e qualquer ideia de moral, toda legalidade, todo o caráter político que tem o outro como base das leis dos direitos humanos. Na verdade, as legítimas hordas animalizadas 
eram os nazistas, não os nativos e muito menos os animais abatidos a tiros. Essa realidade, esse novo real, é posto à prova no momento em que a testemunha começa a falar. A palavra falta. Algo se mantém intraduzível, pendurado, enquanto presença-ausência, com o gato na árvore de uma aldeia da Bielorrússia. A intraduzibilidade do real nos interessa porque não estamos lidando, no cotidiano de nossas vidas, com o real em si, mas com uma projeção do real, com uma ideia, muitas vezes impositiva, do real: "Na verdade, o mundo sensível - nosso mundo - nada tem de especialmente nu, ele é totalmente forjado e constituído por relações que remetem imediatamente à ditadura da figura do real de que parti” (Badiou 15). No livro Em busca do real perdido, Alain Badiou nos lembra que o verdadeiro real não pode ser conceitualizado, apreendido ou estabelecido como forma - o real, literalmente, nos escapa:

A simples realidade do conceito não pode valer como uma autêntica prova do real, já que, precisamente, supõe-se que o real seja aquilo que, à minha frente, resiste a mim, não é homogêneo a mim, não é imediatamente redutível a minha decisão de pensar. Quando muito, posso pretender formular, com semelhante ponto de partida, uma hipótese sobre o real, mas não uma apresentação do próprio real. (Badiou 09)

Desse modo, como alcançar o verdadeiro real? Como traduzi -lo? Desmascarando-o. Rasgando a tela real imposta a nós desde o momento da construção da civilização. É preciso desmontar conceitos, verdades absolutas e noções de normalidade inofensiva: "Eu me admirava muito de ver que o jovem oficial fascista que começou a morar conosco usava óculos. Imaginava que só professores usassem óculos" (Aleksiévitch (b) 61) e "Vi o primeiro alemão de perto... Era alto, tinha olhos azuis. Fiquei tão surpresa: 'É tão bonito, mas mata'. Talvez essa tenha sido minha primeira impressão mais forte. Minha primeira impressão da guerra" (Aleksiévitch (b) 89). Podemos dizer que essa tela real, construída à base de conceitos prede- 
terminados, é o que impossibilita a total integralidade do testemunho dos sobreviventes, pois a todo momento a sua fala é travada quando acontecimentos inenarráveis, portanto, irreais, como o massacre de toda uma vila, se chocam com o real predisposto pelo homem no cotidiano de sua vida, ou seja, o real de uma ideia inexistente da banalidade do mal ou de que jamais um vizinho, para se salvar, poderá mandá-lo à morte. Interessa destacar que essa tela real foi um dos sucessos do regime nazista no massacre dos judeus, pois os judeus jamais acreditariam que um dia o seu extermínio pudesse realmente ser cotado por uma nação inteira, a Alemanha:

\begin{abstract}
Durante centenas de anos eles [os judeus] se haviam acostumado a entender a própria história, correta ou incorretamente, como uma longa história de sofrimento, como o promotor muito bem descreveu em seu discurso de abertura do julgamento; mas por trás dessa atitude houve, durante muito tempo, uma convicção triunfante de que Am Yisrael Chai, o povo de Israel viverá; indivíduos judeus, famílias judaicas inteiras podiam morrer em pogroms, comunidades inteiras podiam ser eliminadas, mas o povo viveria. (Arendt 170-1)
\end{abstract}

Se, por um lado, o testemunho se apresenta intraduzível devido à tela real imposta a nós; por outro lado, o testemunho, através da falta da palavra, é um dos meios possíveis para se chegar ao verdadeiro real - através do escândalo provocado por seus testemunhos: "Quanto a esse ponto, há algo muito instrutivo: a função do escândalo em nosso mundo. $\mathrm{O}$ escândalo sempre se apresenta como a revelação de um pedacinho de real" (Badiou 15). O "pedacinho de real" seria a verdadeira face do homem após a queda do Paraíso?

\title{
2. a falta da palavra
}

Ninguém conseguia falar. Nem a gata miava. Ela passou alguns dias calada. Todos emudeceram. (Kátia Korotáieva, treze anos. Hoje: engenheira hidrotécnica) 
O primeiro desafio da intraduzibilidade do discurso testemunhal que devemos enfrentar é a tentativa, por meio do uso equivocado de uma palavra, de nomear, ou conceitualizar, o massacre de milhões de pessoas que ocorreu na Segunda Grande Guerra. Essa palavra é Holocausto: "O infeliz termo 'holocausto' (frequentemente com $\mathrm{H}$ maiúsculo) origina-se dessa inconsciente exigência de justificar a morte sine causa, de atribuir um sentido ao que parece não poder ter sentido" (Agamben 37). Com a queda do Paraíso, o homem não mais teve acesso à palavra divina, as "coisas não têm nome próprio a não ser em Deus" (Benjamin, 71), perdendo o seu caráter imediato e puro, consequentemente, a linguagem do homem passa a ser marcada, como um castigo divino, pela arbitrariedade, pela não imediaticidade entre palavra e coisa, entre sons e palavra, entre significado e significante, passando a ser uma convenção: "As línguas são conjuntos inteiramente arbitrários de signos e marcas convencionais" (Steiner 47). Se atentarmos bem para essa realidade levantada por Steiner, perceberemos que a palavra, a linguagem, não significa de fato, que não há uma verdadeira fala sendo base de um testemunho, uma vez que toda palavra é lacunosa, é falta, é mentira.

O caráter utilitário da linguagem é uma fabricação humana, uma tela real imposta a nós para o bom funcionamento do mundo. A ideia de que palavra e coisa são imanentes desafia a própria existência das outras línguas, como também mostra o poder de persuasão do homem na formalização do real. Porém, como esse poder de persuasão poderá se manter firme quando temos testemunhas que experienciaram algo que excede a tela real, que excede a possibilidade de nomeação, de dar sentido ao que parece se confundir com uma cruel irrealidade: "Tudo o que estava acontecendo diante dos nossos olhos era assustador e incompreensível. E o que acontecia conosco. Especialmente a morte..." (Aleksiévitch (b) 35). Como assumir esse impossível real? Assumindo-o como tal: "Está aí o gesto fundamental de conquista do real: declarar que o impossível existe" (Badiou 34). É rasgando a tela real que poderemos vislumbrar o verdadeiro real, o real que nos escapa. É preciso assumir a impossibilidade da palavra nomear fidedig- 
namente o ser ou a coisa, é preciso desmontar as formalizações da linguagem elaboradas pelo homem, para podermos abrir uma fenda para que o real, o verdadeiro, assuma o seu posto diante do homem. Com o relato das testemunhas, essa fenda se apresenta de modo vertiginoso no momento de tensão entre o preciso dizer e o não tenho palavras para dizer: "muitas vezes, as suas próprias palavras [das testemunhas] continuam aparecendo como enigma insondável" (Agamben 19).

O recurso à palavra na tradução do impossível real, do genocídio em massa, tem como contrapartida a sua intraduzibilidade, como dito anteriormente, pois a palavra não pode sustentar toda uma realidade excessiva para a qual não foi criada. No entanto, a palavra, mesmo faltosa, é o único meio de testemunhar - essa é a aporia do testemunho: "Perdi a fala, e quando depois de algum tempo comecei a falar, mesmo assim fiquei gago" (Aleksiévitch (b) 42). Em relação à palavra Holocausto, não apenas a tentativa de nomeação é faltosa, como o próprio significado da palavra, no que diz respeito ao acontecido aos judeus e a outras etnias, é bastante equivocado. A definição da palavra Holocausto é antiga, remontando ao período antes de Cristo, embora seja essencialmente cristã, tendo dois significados importantes, como salienta Agamben:

\begin{abstract}
O primeiro, de que o termo, no sentido próprio, é precocemente usado pelos padres como arma polêmica contra os Hebreus, a fim de condenarem a inutilidade dos sacrifícios cruentos [...]. O segundo, de que o termo é extensivo, por metáfora, aos mártires cristãos, com o objetivo de equiparar o seu suplício a um sacrifício. (Agamben 38-9).
\end{abstract}

A segunda definição, a metafórica, é a que se estabelecerá de imediato nas línguas vulgares com o passar dos séculos, assumindo o significado de sacrifício de um ser em nome de uma superioridade sagrada e absoluta. Ora, o que aconteceu nos campos de concentração e nas aldeias da Bielorrússia nada tem a ver com sacrifício

Cad. Trad., Florianópolis, v. 40, n 2, p. 193-220, mai-ago, 2020. 
em nome de um Deus ou em nome de deuses. Nomear de Holocausto o massacre de milhões de pessoas é, no mínimo, desumano:

Pelo contrário, no caso do termo 'holocausto', estabelecer uma vinculação, mesmo distante, entre Auschwitz e o olah bíblico, e entre a morte nas câmaras de gás e a 'entrega total a causas sagradas e superiores' não pode deixar de soar como uma zombaria [...] Quem continua a fazê-lo, demonstra ignorância ou insensibilidade (ou uma e outra coisa ao mesmo tempo) (Agamben 40)

Segundo Agamben (40), a palavra que mais se aproximaria do massacre dos judeus seria a palavra shoá, "que significa 'devastação, catástrofe' [...] o eufemismo aqui não contém escárnio algum", diferentemente do uso da palavra Holocausto.

\section{3. as pseudotestemunhas}

Essas cenas, esses fogos. São minha riqueza. É um luxo eu ter sobrevivido...

(Vássia Khárevski, quatro anos. Hoje: arquiteto)

A shoá é intraduzível. O massacre dos povoados do Leste Europeu é intraduzível. Abaixo, o testemunho de Iúra Karpóvitch, na época com oito anos de idade:

Vi o que não deve ser visto... O que o ser humano não deve ver. E eu era pequeno. [...]

Vi fazerem nossos prisioneiros de guerra cruzar a aldeia. Em longas fileiras. Com capotes rasgados e queimados. Nos lugares onde eles ficavam à noite, a casca das árvores aparecia roída. Em vez de comida, jogavam um cavalo doente para eles. Eles o dilaceravam. 
Vi um trem alemão que descarrilhou à noite e pegou fogo, e de manhã puseram todos os que trabalhavam na ferrovia sobre os trilhos e passaram uma locomotiva por cima deles. Vi atrelarem pessoas a uma charrete. Elas [judeus] tinham estrelas amarelas nas costas. Eram açoitadas com chicotes. Os alemães passeavam alegremente (Aleksiévitch (b) 196)

É intraduzível porque aqueles que testemunham, os sobreviventes, não são as verdadeiras testemunhas, mas pseudotestemunhas. As legítimas testemunhas, aquelas que experienciaram todo o terror e toda a desumanização capaz de ser infligida pelo seu semelhante, o homem, são aquelas que morreram sobre os trilhos ou aqueles que morreram após comerem um cavalo doente. Apenas esses podem ser chamados de verdadeiras testemunhas de guerra. Primo Levi, em Os afogados e os sobreviventes, consciente do seu lugar de sobrevivente de guerra, logo, de uma pseudotestemunha, afirma:

Repito, não somos nós, os sobreviventes, as autênticas testemunhas. Esta é uma noção incômoda, da qual tomei consciência pouco a pouco, lendo as memórias dos outros e relendo as minhas muitos anos depois. Nós, sobreviventes, somos uma minoria anômala, além de exígua: somos aqueles que, por prevaricação, habilidade ou sorte, não tocamos o fundo. Quem o fez, quem fitou a górgona, não voltou para contar, ou voltou mudo; mas são eles, os 'mulçumanos', os que submergiram - são eles as testemunhas integrais, cujo depoimento teria um significado geral. Eles são a regra, nós, a exceção. (Levi 66)

Teria sido preciso tocar o fundo, ter visto a górgona (o verdadeiro real), para ganhar a alcunha de testemunha de guerra. Os sobreviventes são aqueles que se aproximaram, muito ou pouco, do abismo promovido pelos nazistas, mas, por terem escapado, por sorte ou sagacidade, não podem ser testemunhas do massacre inte- 
gralmente. Eles são como um voyeur de guerra - muito próximo para sentir o terror, mas muito distante para poder pensá-lo, pois aqueles que voltaram do fundo, os mulçumanos ${ }^{2}$, emudeceram e deixaram de pensar:

Como nos interessam e perturbam as escolhas emergenciais adotadas pelo fotógrafo clandestino de Birkenau para dar uma consistência visual - onde o não reconhecível rivaliza com o reconhecível, como a sombra com a luz -, uma forma a seu testemunho desesperado (Didi-Huberman 52).

Nessa citação, Georges Didi-Huberman, em Cascas, se refere a um membro (fotógrafo, voyeur e pseudotestemunha) do Sonderkommando ${ }^{3}$ que, na companhia de seus colegas, fotografou a execução de prisioneiros (testemunhas integrais) por asfixia a gás no exato momento da operação do extermínio. De seu trabalho pioneiro, quatro fotografias foram tiradas, constituindo, atualmente, os únicos testemunhos visuais de uma operação por asfixia a gás. Entre o fotógrafo-testemunha e a vítima por asfixia há um abismo intransponível, como entre a pseudotestemunha e a testemunha.

2 "O assim chamado Muselmann, como era denominado, na linguagem do Lager, o prisioneiro que havia abandonado qualquer esperança e que havia sido abandonado pelos companheiros, já não dispunha de um âmbito de conhecimento capaz de lhe permitir discernimento entre bem e mal, entre nobreza e vileza, entre espiritualidade e não espiritualidade. Era um cadáver ambulante, um feixe de funções físicas já em agonia. Devemos, por mais dolorosa que nos pareça a escolha, excluí-lo da nossa consideração". Citação retirada por Agamben (49) do livro Un intelletuale a Auschwitz, de J. Améry.

${ }^{3}$ Sonderkommando: prisioneiros recrutados por nazistas assim que chegavam aos campos de concentração para desempenharem as funções mais críticas no extermínio: enterrar corpos de prisioneiros mortos, atear fogo nos cadáveres, limpar câmaras de gás, retirar dentes de ouro e cabelos dos mortos e outros serviços que os nazistas não executavam. Por mais crítica e ambígua que fosse a situação, aqueles que participavam do Sonderkommando tinham alguns privilégios em relação aos demais prisioneiros. 
O mulçumano, aquele que retorna petrificado do encontro com a górgona, não é mais um homem, nem um não-homem, mas uma figura-limite, como nos lembra Agamben: "É uma figura-limite de uma espécie particular, em que perdem sentido não só categorias como dignidade e respeito, mas até mesmo a própria ideia de um limite ético" (Agamben 70).

Os mulçumanos acabaram por se tornar uma categoria desprezada nos campos, pois a figura do ser humano não mais humano, perambulando sem pensamentos, mais abaixo do que o instinto de sobrevivência de um animal, causava um dissabor nos prisioneiros que desejavam sobreviver a todo custo - aquele que hoje luta pela sobrevivência poderia vir a ser um mulçumano amanhã:

Por isso, a preocupação mais insistente do deportado consistia em esconder as suas enfermidades e as suas prostrações, em ocultar incessantemente o mulçumano que ele sentia aflorar em si mesmo por todos os lados (Agamben 59).

Mas, se "nem sequer o sobrevivente pode testemunhar integralmente, dizer a própria lacuna" (Agamben 48), como, então, ele testemunha, traduz o irreal? Somente há a possibilidade do testemunho quando a pseudotestemunha testemunha em nome da verdadeira testemunha, quando ela cede o seu lugar de fala àquela que não o possui, não possuindo nem mesmo a fala, a possibilidade da comunicação: "Se o sobrevivente dá testemunho não da câmara a gás ou de Auschwitz, mas pelo mulçumano; se ele fala apenas a partir de uma impossibilidade de falar, então seu testemunho não pode ser negado" (Agamben 163). As crianças-adultas, de As últimas testemunhas, testemunham por seus pais assassinados, por seus avós assassinados, por seus vizinhos assassinados, por suas professoras e professores assassinados, e não por elas mesmas. A sua palavra faltosa fala em nome daqueles que não mais se encontram presentes, aqueles que viram de perto a górgona: 
As pessoas se deslocavam pela cidade lentamente, como sombras. Como num sonho... Um sonho profundo... Digo, você via aquilo, mas achava que estava sonhando. Aqueles movimentos lentos... flutuantes... Como se a pessoa não estivesse andando pela terra, mas pela água...

A voz mudava por causa da fome. Ou sumia totalmente. Não se podia definir pela voz: é um homem ou uma mulher? Pela roupa também não era possível, todos estavam nuns trapos. Nosso café da manhã... Nosso café da manhã eram pedaços de papel de parede, papel de parede velho, mas que ainda tinha cola. Cola de farinha. Esse papel de parede... e água fervente... (Aleksiévitch (b) 245)

\section{Traduzir para efeito de lembrança}

Não quero lembrar. Mas as pessoas precisam contar suas desgraças. É difícil chorar sozinha... (Vália Emitróvitch, onze anos. Hoje: operária)

Jean-Luc Nancy, em Maurice Blanchot: passion politique, sobre o período da década de 30 na França, sobre a aproximação desastrosa da Segunda Grande Guerra e sobre a questão ${ }^{4}$ do suposto envolvimento de Maurice Blanchot nos movimentos de extrema direita francesa, nos diz que, em relação aos eventos catastróficos decorrentes da Segunda Guerra, é preciso tempo. É preciso um distanciamento ainda maior para que se possa pensar o catastrófico sem o peso de uma certa sentimentalidade que embote a reflexão lógica sobre os atos de guerra: "Sim, é preciso ainda, certamente, de tempo para que possamos abordar uma e outra história sem

${ }^{4}$ Para uma melhor leitura sobre a questão do suposto envolvimento do escritor Maurice Blanchot nos movimentos de extrema direita francesa, recomento a leitura do meu artigo: Pimentel, Davi Andrade. Maurice Blanchot: política e escrita/ Maurice Blanchot: Politics and Witing. Aletria: Revista de Estudos de Literatura, [S.1.], v. 24, n. 3, (2014): 25-37. Disponível em: <http://www.periodicos.letras. ufmg.br/index.php/aletria/article/view/6334/8670 > . Acesso em: 17 abr. 2020.

Cad. Trad., Florianópolis, v. 40, nº 2, p. 193-220, mai-ago, 2020. 
estarmos demasiadamente submissos aos filtros das expectativas imediatas, às exigências ingênuas (de pureza, de profissão de fé 'de esquerda', etc.)" (Nancy 15-6) 5 . Já Agamben, em $O$ que resta de Auschwitz, toma uma posição contrária:

Não se pode querer que Auschwitz retorne eternamente, porque, na verdade, nunca deixou de acontecer, já se está repetindo sempre (Agamben 106, grifo do autor).

O massacre em massa em Auschwitz e nas aldeias do Leste Europeu é inominável: poderá parecer ingênua tal afirmação, contudo, o trauma deixado pelos nazistas é uma ferida que nunca cicatriza, está desde sempre necrosada: “As pessoas que não viram um ser humano matar outro ser humano são pessoas totalmente diferentes..." (Aleksiévitch (b) 253). A questão que deve ser colocada não é a do tempo, mas a de um dever de memória. Traduzir o intraduzível do horror para que a memória do horror perdure, reste, demore, como um alerta:

O $U r$-Fascismo pode voltar sob as vestes mais inocentes. Nosso dever é desmascará-lo e apontar o dedo para cada uma de suas novas formas - a cada dia, em cada lugar do mundo [...] Liberdade e libertação são uma tarefa que não acaba nunca. Que seja este o nosso mote: "Não esqueçam" (Eco 61)

Em seu atualíssimo livro, O fascismo eterno, Umberto Eco nos lembra que os grandes regimes fascistas e o regime nazista nasce-

${ }^{5}$ Tradução de minha autoria. No original: "Oui, il faut certainement encore du temps pour que nous puissions aborder l'une et l'autre histoire sans être trop soumis aux filtres des attentes immédiates, aux exigences naïves (de pureté, de profession de foi 'de gauche', etc.)".

Cad. Trad., Florianópolis, v. 40, ${ }^{0}$ 2, p. 193-220, mai-ago, 2020. 
ram de um sentimento de impotência das classes médias frustradas, de um desejo pelo tradicional em contraposição à modernidade, da ação pela ação e do desprezo pelos fracos - para citar algumas características do que o escritor define de $U r$-Fascismo ou fascismo eterno. Nessa perspectiva, ecoa o que Hanna Arendt diz em seu livro quando da subida de Hitler ao poder, quando, com o armamento e a eliminação do desemprego, a classe média se viu novamente satisfeita e, não por menos, grande parte da sociedade alemã acatou as decisões de Hitler e viveu um autoengano que durou e dura, certamente, até hoje:

Durante a guerra, a mentira que mais funcionou com a totalidade do povo alemão foi o slogan 'a batalha pelo destino do povo alemão’ [der Schicksalskampf des deutschen Volkes], cunhado por Hitler ou por Goebbels, e que tornou mais fácil o autoengano (Arendt 65).

Sobre a questão do tempo: o slogan do atual governo brasileiro, "Pátria Amada Brasil", é muito semelhante ao slogan nazista ou de outros governos fascistas, o autoengano está em colocar as palavras Pátria ou povo em primeiro plano para confundir e maquiar as reais inclinações de seus governantes. Se, com Hitler, a perseguição às minorias era aberta e mortal; com o atual governo brasileiro, a perseguição se faz de modo aberto e, sobretudo, virtual - o fascismo está sempre à frente com a utilização de novos recursos tecnológicos.

Em ambos os regimes, constatamos uma caça à diversidade $\mathrm{e}$ ao pensar diferente, características que, como define Umberto Eco, são de regimes fascistas:

Como tanto a guerra permanente quanto o heroísmo são jogos difíceis de jogar, o $U r$-Fascista transfere sua vontade de poder para questões sexuais. Esta é a origem de seu machismo (que implica desdém pelas mulheres e uma condenação 
intolerante de hábitos sexuais não conformistas, da castidade à homossexualidade). Como o sexo também é um jogo difícil de jogar, o herói Ur-Fascista joga com as armas, que são seu Ersatz fálico: seus jogos de guerra se devem a uma invidia penis permanente (Eco 54-5)

Vontade de poder, armas, machismo, desdém pelas mulheres e intolerância com os homossexuais são os pilares não confessados - embora alardeadamente confessados no meio virtual pelos filhos, ministros e secretários do presidente atual - do novo governo e, principalmente, do novo presidente do Brasil. É preciso estar sempre atento, fazer resistência, como enfatiza Eco, para que o passado, sempre diligente, não avance o limite que ainda que lhe é imposto. Os mortos não estão no passado, como se pensaria ou como se gostaria de pensar, eles, como dever de memória, estão sempre presentes:

Como a história aterradora da qual esse lugar [AuschwitzBirkenau] foi teatro é uma história passada, gostaríamos de acreditar naquilo que vemos em primeiro lugar, ou seja, que a morte foi embora, que os mortos não estão mais aqui. Mas é justamente o contrário que pouco a pouco descobrimos. A destruição dos seres não significa que eles foram para outro lugar. Eles estão aqui, decerto: aqui, nas flores dos campos, aqui, na seiva das bétulas, aqui, neste pequeno lago onde repousam as cinzas de milhares de mortos (Didi-Huberman 62)

É por isso que é preciso traduzir o intraduzível, mesmo que impossível, para não esquecer:

Primeiro nossa maravilhosa mãe se foi, depois nosso pai. Nós percebemos, sentimos na hora que éramos as últimas. Naquela linha... naquele limite... Somos as últimas testemunhas. Nosso tempo está acabando. Devemos falar.../ Nossas palavras serão as últimas..." (Aleksiévitch (b) 269). 


\section{Referências}

Agamben, G. O que resta de Auschwitz: o arquivo e a testemunha (Homo Sacer III). Tradução de Selvino J. Assmann. São Paulo: Boitempo, 2008.

Aleksiévitch, S. (a) Vozes de Tchernóbil: a história oral do desastre nuclear. Tradução de Sonia Branco. São Paulo: Companhia das Letras, 2016.

Aleksiévitch, S. (b) As últimas testemunhas: crianças na Segunda Guerra Mundial. Tradução de Cecília Rosas. São Paulo: Companhia das Letras, 2018.

Arendt, H. Eichmann em Jerusalém: um relato sobre a banalidade do mal. Tradução de José Rubens Siqueira. São Paulo: Companhia das Letras, 1999.

Badiou, A. Em busca do real perdido. Tradução de Fernando Scheibe. Belo Horizonte: Autêntica Editora, 2017.

Benjamin, W. Escritos sobre mito e linguagem. Tradução de Susana Kampff Lages e Ernani Chaves. São Paulo: Duas Cidades, Editora 34, 2013.

Didi-Huberman, G. Cascas. Tradução de André Telles. São Paulo: Editora 34, 2017.

Eco, U. O fascismo eterno. Tradução de Eliana Aguiar. Rio de Janeiro: Record, 2018.

Freud, S. Obras Completas, v. 14: História de uma neurose infantil ("O homem dos lobos"), além do princípio do prazer e outros textos (1917-1920). Tradução de Paulo César de Souza. São Paulo: Companhia das Letras, 2010.

Hilst, H. Rútilo Nada. In: Da prosa. São Paulo: Companhia das Letras, 2018.

Levi, P. Os afogados e os sobreviventes. Tradução de Luiz Sérgio Henriques. São Paulo/Rio de Janeiro: Paz e Terra, 2016. 
Nancy, Jean-Luc. Maurice Blanchot: passion politique. Paris: Galilée, 2011.

Seligmann-Silva, M. "Apresentação da questão: a literatura do trauma". In: Seligmann-Silva, M. (Org.). História, memória, literatura: o testemunho na Era das Catástrofes. Campinas: Editora da Unicamp, 2003.

Steiner, G. Depois de Babel: questões de linguagem e tradução. Tradução de Carlos Alberto Faraco. Curitiba: Editora da UFPR, 2005.

Recebido em: 02/12/2019

Aceito em: 27/03/2020

Publicado em maio de 2020

Davi Andrade Pimentel. E-mail: davi_a_pimentel@yahoo.com.br. ORCID: https://orcid.org/0000-0001-5519-3792. 